\title{
ISRAILIAT CONTRIBUTION IN CONTEMPORARY EXEGESIS: (THE EFFORT TO ESTABLISH ISRAILIAT WHICH IS SILENCED "MAUQUF" AS A SOURCE OF AN INTERPRETATION)
}

\author{
Mohamad Nuryansah \\ State Institute for Islamic Studies (IAIN) Salatiga \\ m_nuryansah@yahoo.com
}

\begin{abstract}
This paper aims to re-understand the meaning of Israiliyat and its contribution in contemporary exegesis, especially Israiliyat which is mauquf by the mufassir. The author uses the theory of interpretation because this theory aims to produce an understanding of a text in contemporary situations. The results of this research are that Israiliyat mauquf can be used as source of interpretation because it has positive impact in relation to aspect of religion of samawi
\end{abstract}

Keywords: Israiliyat, mauquf, contemporary exegesis

\section{Introduction}

The text of the Qur'an that is global (mujmal) makes the Qur'an has a uniqueness and advantages compared with the other religious texts before, such as the Torah of the Jewish scriptures and the Gospel of the Christian scriptures. Because of its global nature, interacting with the other religion texts is a necessity, without interaction with the other religious texts so the Qur'an is less able to catch its meaning, especially related to the story of long time ago. Interaction, according to the author is the effort to interact the Samawi Religion that has the same source, namely Allah swt. It is not a lack let alone the weakness of the Qur'an, as the opinion of some Western scholars like Abraham Geiger, who claimed that Muhammad had adopted the Hebrew words into the Qur'an and the Qur'an has been much influenced by Jews religion (including in his interpretation), related to faith, doctrine, morals and the story of the Qur'an (Armas, 2002: 25).

The idea of an apologetic and imperialist study of the Qur'an, as proposed by Geiger and his comrades is not relevant in the modern context. Because of in the present, the study of the Qur'an by western scholars is more academically and constructive, so the fear of "used Isräiliyāt" in an interpretation, worries about the Western assumption that the Qur'an or exegesis is influenced by Judaism and Christianity need to be discontinued, even according to the author, in the current contemporary context, Isräiliyāt, which is a tradition of Jews and Christians, should be used as a source of interpretation so that the three Samawi religions Islam, Jews and Christians- can coexist peacefully.

In Islamic tradition, Isräiliyāt is divided into three major groups; 1) Isrāiliyāt which is appropriate with the truth, and in accord with the Qur'an, and valid history so the majority of the interpreters receive the narration; 2) the history of Isräiliya $\bar{t}$ that is contrary to the Qur'an and destroys the aqīdah, so all interpreters agree to reject it; whereas, 3) the narrations that do not justify the Qur'an and also not against it so the majority of interpreters silenced "mauqūf".

From the three categories of Isräiliyāt above, the majority of interpreter only accept Isräiliyāt in the first version, namely Isräiliyāt which is appropriate to the truth, and in accord with the Qur'an, and valid history, as a source of interpretation, while the second version is rejected, and the third version is silenced without being addressed. According to the author, it is reasonable, because the scholars' caution in receiving news that comes from Jews and Christians. Through this paper, the author wants to encourage that Isräiliyāt in silenced 
"mauquf" can also be used as a source of interpretation.

\section{Methods}

The function of interpretation is to produce an understanding of a text in contemporary situations. But not all acts of understanding are intended as a result of an interpretation. This is because an interpretation has at least three specific functions, namely historical function, meaning development function and implication function.

Furthermore, the theory of this interpretation function is used to construct the idea of Israilizyāt by the author, because the function theory of interpretation is one step in looking at a construction methodology of interpretation of a person to a text, where a method of interpretation basically includes three specific functions: 1) Historical function. The historical function is a function of interpretation as an effort to recreate the understanding of the historical author and the historical audience of the text in the context of a contemporary audience (Osborne, 1991: 325); 2) The meaning development function (meaning function). The function of developing this meaning is to generate an understanding of contemporary audiences that may be far beyond the author's understanding of historical texts and the understanding of the historical audiences of historical authors in their position as recipients of the early text; c) implicative function. The function of this implication is to understand the implication of the text meaning is produced by the acts of understanding of contemporary audiences with evolving scientific devices.

\section{Discussion}

The term of isra'iliyat, derived from the Hebrew word (Al-Husain, 1964: 14), which is the plural form of the word isra'iliyah, the form of isim which is attributed to the word of isra'il. Etymologically, it means a servant of god, Isra 'means servant and Il means God (Wajdi, 1971: 20). For the historical aspect, Israel is closely related to the descendants of Prophet Ya'qub bin Ishaq bin Ibrahim A.S. where his twelve descendants are called Bani Isra'il (AlZahabi, 1971: 20). The term of Isra'il in the Qur'an is used as the name of the Prophet Ya'qub A.S. so that to him the Jewish nation is attributed and called "Bani isra'il", as the meaning of Q.S. Ali Imran (30): 93: "All food was lawful unto the Children of Israel, save that which Israel forbade himself, (in days) before the Torah was revealed. Say: Produce the Torah and read it (unto us) if ye are truthful." Similarly, the explanation of the hadith narrated by Abu Dawud alTayalisi from Abdullah bi Abbas R.A. "A group of Jews has come to the Prophet SAW. Then he said (ask) to them: 'do you know that the Isra'il is the Prophet Ya'qub A.S.? They replied: 'Right', then the Prophet prayed: O my Lord! Watch their confession! " (Syakir, 1956: 138).

Terminologically, according to the view of Mufasir and Hadith Isra'iliyat is a story or event narrated from the source of Isra'ili. In the book entitled Al-Isrāiliyāt Fì Al-Tafsìr wa Al-Hadīth, Husain Al-Zahabi gives two insights; 1) the ancient stories and tales that infiltrated into tafsir and hadith, which originated from the source of Jewish, Christian or other sources; 2) stories deliberately smuggled by the enemies of Islam into tafsir and hadìth, which are not found at all essentially in old sources, such as misappropriation of the marriage story of the Prophet Muhammad SAW with Zainab bint Jahsy, the former wife of adopted son of Zaid bin Harisah (Al-Zahabi, 1971, 25). Khalil defines that Israilayat as the story or narrations of the scriber, both of which have the relationship with the religion precept or not. (Khalil, 1972, 113)

Basically, Israiliyat does not only refer to the history that originated only among the Jews, but also the history that comes from the Christians, it's just a term that is used closer to the Jewish Religion because Jews who convert to Islam more than the Christians or also because the prominence of their role towards Muslims who have been so close since the beginning of Islam (Suryadi, 1997: 30). So even though the Jews are more dominant in the related story of Israiliyāt, Christians also contribute to the influence of Islamic treasures. 


\section{Isrāiliyāt in the historical of interpretation}

The effect of the story of Isräilyyāt in the exegesis of Qur'an also in the hadith can not be separated from the socio-cultural conditions of the Arab community at that time. Because interaction of Jewish and Christian culture can not be avoided by Islam. Because it becomes a fitrah, or maybe it is God's scenario to have a dialogue between the Samawi Religion continues. The conditions of the two cultures - Jews and Muslims - which gave to different ideas led to dialogue both of them. The Jews often asked to prophet Muhammad SAW related to his truth as Prophet and Rasul. However, because of the truth of the nubuwah and the treatise of Islam along with the Qur'an as a guide to his life can be proved concretely, Rasul can draw to them convert to Islam, such as Ka'ab al-Ahbar, Abdullah ibn Surayya, and Abdullah ibn Salam (Al-Zahabi, 1971: 24).

In the era of the Prophet Muhammad, information related to the history of Isra'iliyyat even though the hadith, because the Prophet became the only explanation (mubayyin) to the various problems and problems faced by the ummah. So the Prophet became the only source of consultation, consolidation, and confirmation. Nevertheless, the Prophet had given the "green light" on Muslims to receive information or disseminate information from the Bani Isrāil/Isräiliyāt: as the hadith of the Prophet: "deliver what comes from me even one verse. And tell (what you hear) from the Bani Isrāill and (it) there is no harm. And whoever lies over me, then be prepared to occupy his place in the hell (Bukhārī, 2000: 234). Similarly, in another hadith, he said: "Do not justify the scriber and do not deny them. Say all of you that we all believe in Allah and what is revealed to you (Bukhārī, 2000: 234). Thus, the Isräiliyāt has developed in the time of the Prophet, but not yet a necessity, because everything can be asked directly to the Prophet, without need another instrument to understand the religion.

But the need for Isräiliyāt after the passing away of the Prophet, being a treasure to be attention, because in the religious affairs, no one has the right to be the explainer (mubayyin) of God's revelation. Thus the Companions do the interpretation of religious texts with ijtihād, if they face the problems, such as interpreting the stories of the Prophet or the ancient ummah, using the aid of the Torah as well as the Gospel (Al-Zahabi, 1971: 169). Because the Qur'an describes the old story succinctly.

The famed Isräiliyāt sources of the Jews are Abdullah ibn Salam, Ka'ab al-Ahbar, Wahab ibn Munabbih, and 'Abd al-Malik ibn' Abd al-'Aziz ibn Juraij; while among the Companions are: Abu Hurairah, Ibn 'Abbas, and' Abdullah ibn 'Amr ibn' Ash. They are the second source.

Israiliyāt developed in the era of the companions quickly. But in accepting the narrations from Jews and Christians, the Companions are very selective. They just restrict to the stories in the Qur'an that have been described globally. So when they find Isräiliyāt stories that contradict with the Shari'ah of Islam they immediately reject it. On the contrary, if the stories of Isräiliyāt are true, so they accept it. Whereas if the stories were debated, they suspended them (mauqüf). Thus, the Companions only accept the Isräiliyāt story if found the legitimacy of the Qur'an and the hadith of the Prophet. The main motivation of entering Israilizāt by companion in interpreting the Qur'an is to broaden the horizon in interpreting the Qur'an (Al-Zahabi, 1971: 92-93). So the Isräiliyāt criteria accepted by the Companions; 1) appropriate with the spirit of the Qur'an; 2) the sanad is valid; 3) appropriate with reason.

But in the time of the Tabiin, which narrates much of Isräiliyāt is Ka'ab al-Ahbar and Wahab ibn Munabbih. the rawi of Israiliyat is uncontrolled and less selective in this period, many of the history of hadith that do not go through of "ethic codes of research methodology" of the sciences of hadith, it does not write sanad completely. As a result, there have been many history in interpreting of the Qur'an that is infiltrated of Isräiliyāt carelessly (Al-Zahabi, 1971: 92-93). 
In further development, post-tabi'in, the narrator who narrated israiliyat is Abdullah Malik ibn Abdul Aziz ibn Juraij and Muqatil ibn Sulaiman (Al-Zahabi, 1971: 111). This period is the era of bookkeeping exegesis of qur'an. Many works of exegesis are produced by the scholars in this period. These are: Tafsir Muqatil $(\mathrm{w} .150 \mathrm{H})$, tafsir al-Farra $(\mathrm{d} .207 \mathrm{H})$, Tafsir al-Tabari $(301 \mathrm{H})$, Tafsir al-Sa'labi (w.427 H), Tafsir Ibn Katsir (w.747 H), and others. However, because of these exegeses do not include the sanad to hadith explicitly, so it makes in a mixture of valid history and an invalid history so influenced on the stories of Isrāiliyāt.

Khazanah of Isräiliyāt which is so proportioned to be viewed differently by some Western scholars. Many works have suggested that the Qur'an is a copy of Judaism, or the assumption that Muhammad is a disciple of a Jew. This can be seen from the work of Abraham Greiger, Richard Bell, and others.

Al-Zahabi (1971: 159) classifies the exegetical texts containing of Isräiliyāt stories, as follows; 1) The exegetical texts containing Isräiliyāt complete with the sanad, but lacking in criticism, such as al-Thabari (w.301) entitled Jami 'al-Bayan fi tafsir Qur'an; 2) The book containing of Isräiliyāt complete with sanad, and criticizing the failure of its sanad, like Tafsīr Ibn Kasīr (w.774 H) namely Tafsir Al-Qur'an al-Azim; 3) The exegesis book that narrated Isräiliyāt as it is, without mentioning sanad or giving the comment nor explaining where the history is true and false, such as Tafsir Muqatil ibn Sulaiman (w.150 H) ; 4) The exegetical book which narrated the Isra'iliyyat without sanad, occasionally pointing out their weaknesses or expressing their disagreement clearly, but sometimes it does not give criticism at all, although the history contradict to the Shari'ah of Islam, such as Tafsīr al-Khāzin $(741 \mathrm{H})$ entitled Lubāb al-ta'wīl fì Ma'āni al-Tanzīl; 5) The book of exegesis that narrated Isrāiliyāt without sanad aims to explain its falsity or failure. This exegesis is very strict criticize the Isrāiliyāt, like al-Alūsī's exegesis of al-alāsī (w.1270 H) namely Rūh al-Ma'ānī fì tafsīr alQur'ān wa al-Sab al-Masāni; 6) Book of exegesis sues strictly mufassir who take Isrāiliyāt in his exegesis. From their attacks, these authors dare to give wrong accusations to the Isräiliyāt story, even though they consist of the elected comrade of Tabi'in. Although in the reality the author of the book is also similar in situation, it means that - unconsciously - he displays the story of Isräiliyāt in his exegesis, such as Tafsir Rashid Rida (w.1354), called Tafsīr al-Manār.

\section{The Opinion of Mufasir about Isra'iliyat}

Some scholars' opinion of Isräiliyāt 1) Ibn Taimiyah divides into three forms of Isrāiliyāt, a) Isräiliyāt which is appropriate with Islam needs to be justified and narrated, b) Isräiliyāt which is not appropriate with Islam must be rejected, c) Isräiliyāt which does not include between the two parts of it must be mauqu$f$, but it can be narrated; 2) Ibn Khaldun allows to reference to the scribes, but should be selective, because the history of the scribes are valid and some are wrong; 3) Muhammad Abduh rejected strongly to the history of Israiiliyāt, and criticized the early generation interpreters who used Israiliyyat in the interpretation of the Qur'an, with Isräiliyāt can destroy the understanding of Islam; 4) Rashid Ridha affirms that the Isräiliyāt who narrated by the scholar is out of the context of the Qur'an (Anwar, 1999: 43).

\section{Isrāiliyāt in the Indonesian exegesis}

Most all exegeses, including the exegesis in Indonesia interacts to the Isräiliyāt as AlAzhar exegesis by Hamka. According to the author the using of Isräiliyāt in Hamka's exegesis is proportional because he mentions the history of Isräiliyāt with the source of the history, and the society are allowed to judge the story of the Isräiliyāt from the perspective of the Qur'an and Sunnah and common sense. When the story of Isräiliyāt is appropriate with AlQuran and does not damage aqĩdah, so it is allowed to be made as an i'tibār. As the name of the individual whose Qur'an itself does not mention it clearly. However, if the history 
damages the aqidah, he quotes it to be criticized and rejected firmly. So according to Hamka, Isrāiliyāt can be used as a source of interpretation when the history of Isrāiliyāt is appropriate with the Qur'an, valid and not contrary to the reason (Hamka, 2015: 52)

\section{Isräiliyāt contribution in the contemporary exegesis}

In a contemporary context, Isräiliyāt needs to be considered to be a source of interpretation, especially with regard to the stories in the Qur'an. as well as mauqu $f$ the scholars' as long as the valid sanad, do not damage the aqidah, and appropriate with the universal values of humanity, so according to the author it can also be used as a source of interpretation. Because according to the author with the existence of Isrāiliyāt produce several advantages, in developing the global life; 1) developing peace in the earth because scripture interact with each other; 2) interacting with other khazanah religious will create a tolerant and respectful attitude, so truth claims can be avoided; 3) realizing the Qur'an as a key in building a harmony among religious people.

\section{Conclusion}

Based on the above analysis, it can be concluded that Isräiliyāt can be used as a source of interpretation as long as Isräiliyāt is not destroy the belief "aqīdah" and appropriate with universal human values. Because in addition to extending the treasury "khazanah" of Isräiliyāt exegesis build a harmonious relationship with other religious people, especially the divine religion, which comes from Allah swt.

\section{References}

Ahmad, Khalil. (1972). Dirāsah fì al-Qur'ān, Mesir: Dār al-Ma'ārif.

Al-Bukhārī, Muhammad ibn Ismāil. (2000). Sah̄̄h al-Bukhārī. Beirut: Dār al-Fikr.

Al-Zahabi, Husain. (1971). Al-Isrāiliyāt Fì Al-Tafsīr wa Al-Hadīs. Kairo: Majma' alBuhūs al-Islamiyah.

Al-Husain, Khalaf Muhammad. (1964). Al-Yahüdiyah bain Al-Masihiyah wa Al-Islām, Mesir: al-Muassasah Al-Ammah.

Anwar, Rasihan. Melacak unsur-unsur Israiliyat dalam tafsir at-thabari dan tafsir ibn katsir. Bandung: CV Pustaka Setia.

Armas, Adnin. (2002). Metodologi Bibel Dalam Studi Al-Qur'an. Jakarta: Gema Insani. Hamka. (2015). Tafsir al-Azhar. Jakarta: Gema Insani.

Syakir, Ahmad Muhammad. (1956). 'Umdah al-Tafsīr 'an al-hāfid Ibn Katsīr. Mesir: Dar AlMa'arif.

Wajdi, Muhammad Farid. (1971). Dāirah Al-Ma'ārif. Beirut: Dār al-Ma'arifah. 